\title{
A review of paraoxonase 1 properties and diagnostic applications
}

\author{
M. Kulka \\ Department of Pathology and Veterinary Diagnostics, Faculty of Veterinary Medicine, \\ Warsaw University of Life Sciences, Nowoursynowska 159c, 02-776 Warszawa, Poland
}

\begin{abstract}
Paraoxonase 1 (PON1) is an arylesterase associated with serum high density lipoprotein particles. Its name is derived from hydrolyzing one of several organophosphate compounds, namely paraoxon. Recent studies have shown that PON1 plays a protective role in diseases associated with oxidative stress such as atherosclerosis and diabetes mellitus. Studies have demonstrated reduction-oxidative state changes involving PON1 in humans and laboratory animal models. Although there is less information about the role of this enzyme in veterinary medicine, new data suggest that PON1 might be a new oxidative stress marker in animal patients, similarly to humans.
\end{abstract}

Key words: PON1, properties, diagnostic applications

\section{Introduction}

Paraoxonases are a family of enzymes with esterolytic properties, hydrolyzing organophosphate compounds. There is evidence suggesting that some play a protective role against oxidative stress. There are several publications about enzyme coding, structure, activity and changes in concentration in mice, other laboratory animals and in humans. However there is only a small amount of information about this enzyme in other species.

\section{PON1 synthesis and high density lipoprotein association}

In mammals the PON family is coded by 3 distinct genes. Human PON genes are located on the long arm of the 7th chromosome (7q21.3-q22.1). In the mouse - on the 6th arm, near D6Mit86 (Sorenson et al. 1995). Synthetized in liver, PON1 and PON3 can be found in plasma whereas PON2 is primary an intracellular enzyme.

PON1 (E.C. 3.1.8.1.) is associated with high density lipoproteins (HDLs). Human HDLs are a heterogeneous group of lipoproteins which may be classified according to their increasing size: $\mathrm{HDL}_{3} \mathrm{c}, \mathrm{HDL}_{3} \mathrm{~b}$, $\mathrm{HDL}_{3} \mathrm{a}, \mathrm{HDL}_{2} \mathrm{a}, \mathrm{HDL}_{2} \mathrm{~b}$ (Rosenson et al. 2011). In healthy individuals the highest PON1 serum activity, using ultracentrifugation and automated fractionation methods, was found in the HDL subfraction with density ranging from $1.175-1.185 \mathrm{~kg} / \mathrm{L}$, with a maximum activity at $1.18 \mathrm{~kg} / \mathrm{L}$. This is the $\mathrm{HDL}_{3}$ subclass $(\mathrm{Be}-$ rgmeier et al. 2004). In addition, Gugliucci et al. (2013), using different methods, confirmed PON1 activity in the smaller particles $\left(\mathrm{HDL}_{3} \mathrm{c}\right)$. In their study the activity was measured in situ after native gel electrophoresis in 18 human males and 15 females in good health. 
In bovine serum over $85 \%$ of paraoxonase and arylesterase activity was also measured in HDL fractions. Four classes of HDL fractions can be distinguished in Holstein Friesian and Japanese Blacks based on size. HDL-1 with 13.8 - $14.9 \mathrm{~nm}$, HDL-2 with 12.0 - $14.5 \mathrm{~nm}$, HDL-3 with 11.5-13.5 nm and HDL-4. HDL-4 corresponds to heavy HDL (Bauhart 1993) ranging from 9.2 to $12.1 \mathrm{~nm}$ in which the PON1 presence was mainly detected. Less than about $5 \%$ of PON1 activity for both substrates was found in very low density lipoprotein (VLDLs) and low density lipoprotein (LDLs) fractions. In the Holstein Friesian, Japanese Blacks, Swiss Blacks and Montofon bovine breeds PON1 was identified as $43 \mathrm{kDa}$ protein (Miyamoto et al. 2005, Erzengin et al. 2014).

PON1 is associated with the major HDL structural Apolipoprotein A-I (Apo A-I) (Mackness et al. 1988). PON1 - Apo A-I binding occurs with high affinity and leads to increased enzyme stability. Furthermore, it also influences lactonase activity (Gaidukov et al. 2010). These facts suggests that the lipoprotein might be a physiological acceptor for PON1. In a study published by Deakin et al. (2002) the authors described adding HDL particles (containing apolipoproteins A-I and A-II) to hepatic and ovary transfected cell cultures expressing enzymatically active human PON1 (hPON1) on the external cellular membrane surface. In addition the enzyme arylesterase activity was confirmed on non-permeabilized cells by adding phenyl acetate. After HDL incubation with hepatic and ovary transfected cells for an indicated period of time, a 2-3-fold PON1 activity increase in the culture media was measured. Moreover, a significant cell-bound PON1 activity depletion was seen in the presence of HDL. This indicates a possible role of lipoproteins in PON1 detachment from the external surface of cell membranes. PON1 binding to the HDL might not be permanent. Experiments with hamster ovary and human endothelial cells demonstrated that PON1 associated with HDL could be transfered onto the external face of the plasma membrane of the cells without losing its activity (Deakin et al. 2011). Moreover, data showed that the HDL scavenger receptor class $\mathrm{B}$ member 1 (SR-BI) plays a crucial role in the transfer process. Downregulated expression of this receptor, due to siRNA, was correlated with decreased transfer efficiency (Deakin et al. 2011).

\section{PON1 substrates, polymorphism influence}

A variety of synthetic and natural substrates are hydrolyzed by PON1. Aldrige (1953) classified PON1 as an A-esterase, an enzyme hydrolyzing organophosphates and aromatic esters, while B-esterase enzymes, such as cholinoesterases and serine carboxylesterases, were inhibited by paraoxon or other organophosphates.

PON1 hydrolysis oxon metabolites in most mammals (Carr et al. 2015). Experiments with PON1 knockout mice showed a dramatic sensitivity increase to diazoxon exposure, which resulted in $80 \%$ inhibition of cholinoesterase in comparison to wild type mice. Administration of higher doses was lethal to the strains without PON1 expression and had no effect on wild mice with functional PON1. PON1 catalytic efficiency differ depending on the substrate type, and are higher towards i.e. chlorpyrifos oxon and diazoxon, than its esterolytic abilities towards diazinon and paraoxon (Li et al. 2000). Its activity also differs between species, PON1 activity is higher in rabbits and rats than in cows, pig and horses (Carr et al. 2015). Another group of synthetic substrates are aromatic esters. These include phenyl acetate, 2-napthyl acetate and thiophenyl acetate. The most common substrates used to assess PON1 activity in experiments include paraoxon and phenyl acetate.

All paraoxonases hydrolyze aromatic and long chain aliphatic lactones such as dihydrocoumarin or 5-hydroxy-6E,8Z,11Z,14Z-eicosatetraenoic acid (5-HETE) lactones. PON1 lactonase activity might have an influence on administrated drugs used during treatment. Examples include human PON1 activity on prulifloxacin or human PON3, which hydrolyzes the statin lactones lovastatin and simvastatin or diuretics such as spironolactone (Draganov et al. 2005), used in human and veterinary medicine (Schuller et al. 2011).

A natural group of PON1 substrates comprised cell membrane associated phospholipid hydroperoxides (Ferretti et al. 2004), lipoprotein hydroperoxides and cholesteryl esters. Incubation of oxidized HDL with purified PON1 for 2 hours reduced lipoprotein peroxides by $19 \%$ and reduced HDL cholesterol linoleate hydroperoxides by $90 \%$. Paraoxonase activity was also shown when HDL-associated and purified PON1 were added to a hydrogen peroxide solution. After 120-minutes incubation a time-dependent reduction of $\mathrm{H}_{2} \mathrm{O}_{2}$ up to $25 \%$ was seen in the solution (Aviram et al. 1998B). Oxidized-LDL phospholipids and cholesteryl esters, as products of the atherosclerosis process, are physiological substrates for PON1. Thus, paraoxonase acts to protect LDLs against oxidation (Aviram et al. 1999). Inactivated HDL-associated PON or purified PON (by usage of specific inhibitors) stimulated LDL oxidation when incubated together with $\mathrm{CuSO}_{4}$ in solution.

In addition, PON1 polymorphism influences enzyme activity characteristics in humans and rabbits, where 3 phenotypes can be seen. Addition of saline stimulated a trimodal pattern first found in the Cau- 
casian population in the United States, where phenotype A was characterized by paraoxonase/arylesterase ratio $(\mathrm{P} / \mathrm{A})$ of $1.21 \pm 0.19$, phenotype $\mathrm{AB}$ by a $4.68 \pm 0.85$ ratio and phenotype $\mathrm{B}$ by a $8.36 \pm 0.70$ ratio (Eckerson et al. 1983). Human PON1 gene polymorphism determines protein enzymatic activity towards some substrates. 192R PON1 with arginine at the 192nd position (corresponding to the hPON1 phenotype B) hydrolizes paraoxon six times faster than PON1 with glutamine at 192nd position - 192Q (which corresponds to the hPON1 phenotype A). However, hydrolysis of some lactones and esters is different, with PON1 $1_{192 \mathrm{Q}}$ hydrolyzing $\gamma$-butyrolactone with $\mathrm{V}_{\max } 420$ $\mathrm{U} / \mathrm{mg}$ while PON1 $1_{192 \mathrm{R}}$ almost two times lower - 290 $\mathrm{U} / \mathrm{mg}$ (Billecke et al. 2000). Another substrate, phenyl acetate, is hydrolyzed by $P O N 1_{192 \mathrm{Q}}$ with $\mathrm{V}_{\max }$ is 845 $\mathrm{U} / \mathrm{mg}$ while $\mathrm{PON} 1_{192 \mathrm{R}}$ hydrolyzes slower with $\mathrm{V}_{\max } 720$ $\mathrm{U} / \mathrm{mg}$ (Aviriam et al. 1998A).

Serum paraoxonase has been purified from many species but polymorphism presence and different activity patterns have not been well studied. Other animals with intensively characterized PON1 proteins are rabbits. PON1 activities towards paraoxon and phenyl acetate were measured in inbred strains and outbred New Zealand White rabbit sera and $\mathrm{P} / \mathrm{A}$ ratios were examined. Rabbit strains were classifed as A (rPON1A) and B (rPON1B) depending on whether their respective $\mathrm{P} / \mathrm{A}$ values were below 3.5 or above 4.5. Furthermore, in a homogenic group of New Zealand White rabbits a trimodal pattern in $\mathrm{P} / \mathrm{A}$ ratio was seen. Three phenotypes where characterized: $\mathrm{A} \leq 2.2, \mathrm{AB}=2.3-3.6, \mathrm{~B} \geq 3.7$. These polymorphisms correlated with three nucleotide changes in alteriation of aminoacids (P82S, K93E, S101G) in exon 4. The aminoacids S82, E93, G101 corresponded to rPON1A while P82, K93, S101 corresponded to rPON1B (Watson et al. 2001).

However, different PON1 phenotypes cannot be described in all examined animals. The bovine PON1 paraoxonase/arylesterase ratio in Holstein-Friesian, Polish Red and Norwegian cattle was constant suggesting there is no trimodal distribution like in humans and rabbits, when using two enzymatic activities towards paraoxon and phenyl acetate (Kulka et al. 2014, Kulka et al. 2016). Also no trimodal pattern was observed in Japanese Black breed where both activities where correlated (Miyamoto et al. 2005).

\section{PON1 activity}

Studies indicate (Aviram et al. 1998A, Aviram et al. 1998B) that PON1 might have two separate active sides for esterolytic and hydroxyperoxide activities, which differ in their mechanisms. One, with hydrolytic activity, would metabolize substrates such as esterified lipids. The other would take part in hydroperoxides reduction. It is proposed that both might play in concert in vivo, with the esterolytic side generating the preferred substrates i.e. free fatty acid hydroperoxides for further reduction by the second active side. Data presented by Karabina et al. (2005) agree with this concept, where the oxidized form of linoleic acid ester, namely p-nitrophenyl 13-hydroperoxylinoleate (pNPHPODE), was used as a substrate for PON1. The reduction paralleled hydrolysis indicating esterolytic activity requirement before the estrified fatty acid hydroperoxide was reduced.

The PON1 hydroxyperoxide-reducing activity was not affected by the presence of chelating factors unlike esterolytic activity, which was lower in samples collected using EDTA or citrate (Karabina et al. 2005). Furthermore, modification of cysteine free sulphydryl group at the 283rd position in PON1 influenced its enzymatic activity. Inactivation of - $\mathrm{SH}$ by blocking it using iodoacetate caused a significant reduction in LDL oxidation inhibition, whereas minimally affected arylesterase activity. Simillar effects were accomplished when using recombinant PON mutants in which the cysteine at $283 \mathrm{rd}$ position was changed (and in the same manner the residue of amino acid) to serine (Cys283Ser) or alanine (Cys283Ala). The amino acid replacement also led to reduced enzyme activity and PON1 mutants were unable to inhibit LDL oxidation (Aviram et al. 1998A).

Oxidation itself next to the enzyme polymorphism, cysteine residue changes, and different anticoagulant usage could also modify PON1 efficiency. There are several reports about oxidative inactivation of paraoxonase (Cao et al. 1999, Jaouad et al. 2003).

It is likely that in experimental environmental conditions PON1 activity was suppressed due to reactive oxygen species generation (Nguyen and Sok 2003). Addition of antioxidants such as vitamin $\mathrm{E}$ in some assays preserved the PON1 inactivation, where pyrrolidine dithiocarbamate (PDTC), a strong antioxidant, completely preserved the PON1 hydrolytic activity (Karabina et al. 2005). What is interesting a similar protection of enzyme activity was seen when $1 \mathrm{M}$ of glucose was used, suggesting that very high concentrations might be self-quenching. This is in contrast to an esterolytic activity loss obtained by incubation with glucose in lower (physiologically normal) and slightly elevated concentrations - respectively $5 \mathrm{mM}$ and $100 \mathrm{mM}$ (Karabina et al. 2005).

Although PON1 has a high affinity to HDL, when PON1 protein is transferred from serum to cell membranes it still possesses its antioxidant abilities. When culture cells with membrane bound PON1 were incubated with ox-LDL or 2,2'-azobis(2-amidinopropane) 


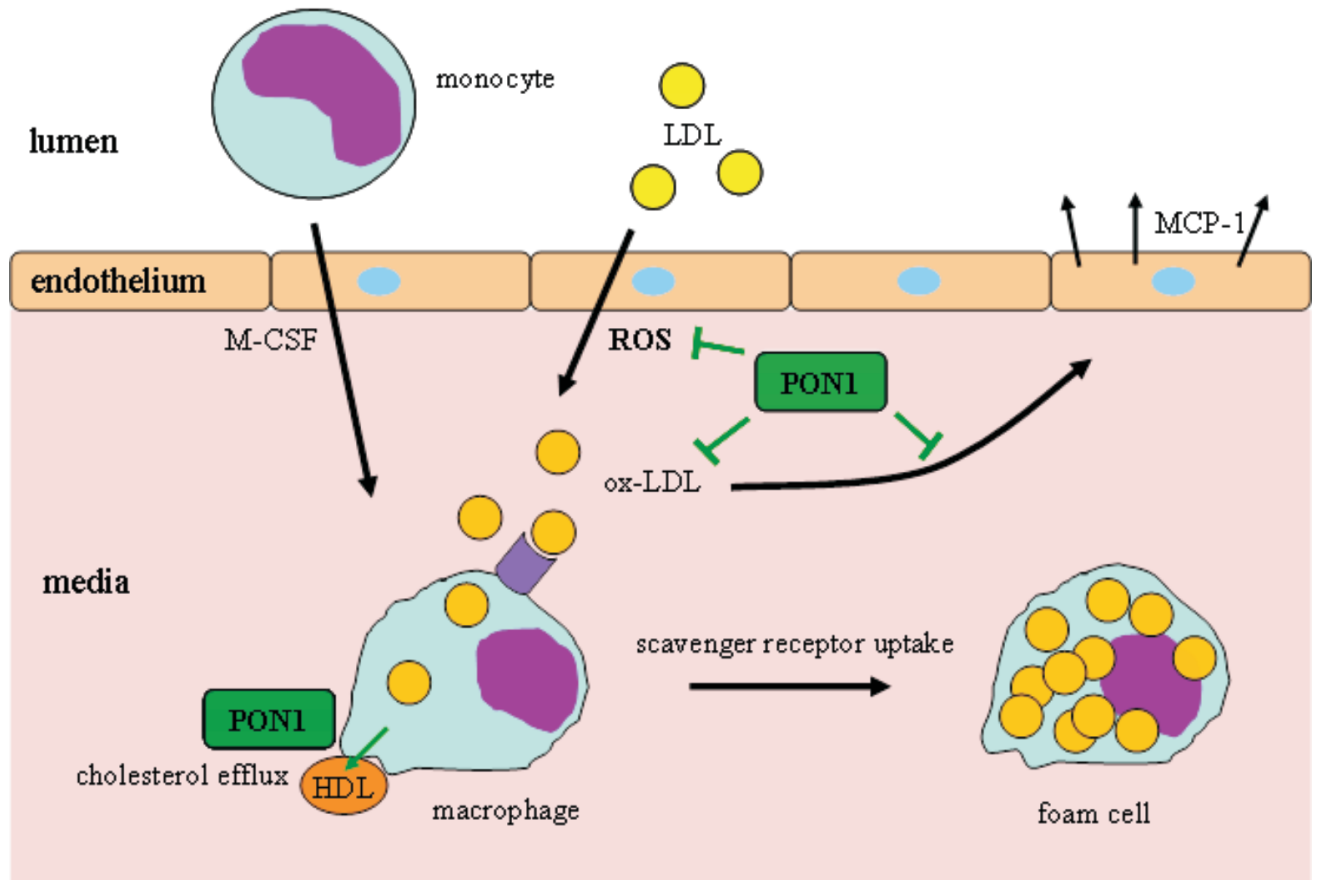

Fig. 1. PON1 protective function against foam cell formation and plaque development in atherosclerosis. Monocytes enter an artery wall media (stimulated by M-CSF and MCP-1), where they are loaded with ox-LDL and transformed to foam cells. PON1: - inhibits the LDL oxygenation process by ROS and therefore leads to oxidized low-density lipoproteins decrease; - increases the enhancement of cholesterol efflux from macrophages. PON1 also diminishes monocyte chemoattractant protein-1 synthesis by endothelial cells thus leading to a decrease in foam cells formation. PON1 - paraoxonase 1, ROS - reactive oxygen species, MCP-1 - monocyte chemoattractant protein-1, HDL - high density protein, LDL - low density protein, ox-LDL - oxidized low-density lipoprotein, M-CSF - macrophage colony-stimulating factor (Camps et al. 2012, modified).

hydrochloride (AAPH) (experimental sources of induced oxidative stress) the intracellular induced stress was singnificantly reduced (Deakin et al. 2011).

\section{PON1 as a member of the acute phase proteins (APP)}

PON1 is treated as a negative acute phase protein and its concentration decreases during inflammatory conditions. In humans and rabbits during acute phase response, Apo A-I levels and PON1 activities were simultaneously depleted (Van Lenten et al. 1995). It seems that under inflammatory conditions displacement of Apo A-I by the positive acute phase protein - serum amyloid A (SAA) in HDL might occured, thus leading to a decrease in PON1 activity. However, in mice with acute infection a decrease in PON1 and platelet activating factor acetylhydrolase (PAF-AH) activities was concomitant with unchanged Apo A-I levels (Van Lenten et al. 2001).

Acute phase response induced by endotoxin, lipopolysaccharide (LPS), caused a decrease in PON1 serum activity (over 60\%) within 48 hours in Syrian Hamsters and initiated a rapid decrease in PON1 mRNA concentrations persisting for at least 48 hours in hamster hepatic cell cultures. Moreover, it was observed that mediators such as Tumor Necrosis Factor (TNF) and IL-1 diminished PON1 activity in a similar manner (Feingold et al. 1998).

Clinical studies involving individuals confirmed previous in vitro observations with LPS administration. PON1 plays in concert with other APPs during the inflammatory process.

PON1 negative acute phase response changes with concominant elevation of APP positive were measured in severe conditions in human sepsis and animal parasitic infections. People in critical states during infection had decreased PON1 activity and a significant negative correlation with $\mathrm{C}$ reactive protein (CRP) (Novak et al. 2010) which is a well studied positive acute phase protein (Gewurz et al. 1982, Jain et al. 2011). Similar changes can be seen in canine heartworm disease. Dogs infected with Dirofilaria immitis (amicrofilaremic, microfilaremic) had reduced PON1 activity, decreased albumin concentration (APP negative) and a negative correlation with CRP concentrations in serum. However, there was no difference in negative acute phase protein levels between asymptomatic or symptomatic (cough, lung crackles, ascites, cachexia, exercise intolerance) antigen positive dogs, suggesting that CPR is a more universal marker in dirofilariosis (Mendez et al. 2014). 


\section{PON1 changes in different diseases}

Changes in the redox state can be encountered in many diseases e.g. atherosclerosis, diabetes mellitus, obesity, chronic liver inflammation. Similar changes also occur in physiological processes, such the periparturient state. PON1 involvement is being intensively studied to assess its function and potential applications as an additional marker in diagnostics and in monitoring patient health.

Several experiments have shown PON1 to have a protective function in atherosclerosis (Mackness et al. 2004, Camps et al. 2012). In this process modifications of lipoproteins, such as oxidation, might lead to foam cell formation crucial for lipid plaque development (Fig. 1). Foam cells are created by rapid receptor uptake of oxidized LDL (ox-LDL) and depot in macrophages. In vitro uptake of unchanged LDL particles by those cells is very slow. In mice with PON1 knockout, macrophages have shown increased oxidative stress and reduction of cellular glutathione concentrations (an antioxidant) (Rozenberg et al. 2003), thus leading to LDL oxidation and resulting in macrophage foam cell formation (Aviram and Rosenblat 2004). In addition, mice lacking PON1/apo E proteins exhibited more severe atheroslerotic changes as their LDL particles were more sensitive to oxidation (Shih et al. 2000). Results in rodent models were similar to those in human patients. People with coronary heart disease determined by angiographic evaluation had an increase in LDL-cholesterol concentrations $(133 \pm 45 \mathrm{mg} / \mathrm{dl})$ in comparison to healthy patients $(121 \pm 27 \mathrm{mg} / \mathrm{dl})$. Also a trend in PON1 activity decrease was observed in patients with heart disease $41.6 \pm 26.8 \mathrm{U} / 1$ (control 52.3 $\pm 30.5 \mathrm{U} / \mathrm{l}$ ) (Azarisiz et al. 2003).

PON1 is also responsible of inhibiting monocyte chemoattractant protein-1 (MCP-1) produced by endothelial cells in atherosclerosis (Fig. 1). The upregulation of MCP-1 secrection by ox-LDL is one of the primary events leading to plaque formation (Lusis 2000). Purified PON1 or HDL containing PON1 inhibit the ox-LDL stimulated MCP-1 production. In contrast, avian HDL (which lacks PON1) do not supress this process (Mackness et al. 2004). It has been shown that paraoxonase, due to its activity, prevents LDL-derived oxidized phospholipid formation (ie. 1-palmitoyl-2(5-oxovaleroyl)-sn-glycero-3-phosphorylcholine (POVPC) and 1-palmitoyl-2-glutaroyl-sn-glycero-3-phosphorylcholine (PGPC)). Both stimulate adhesion of monocytes to the endothelium and the production of MCP-1 (Navab et al. 2001). Another anti-atherosclerotic role of PON1 might be the formation of lysophosphatidylcholine (LPC) in macrophages (Rosenblat et al. 2005) which enchances HDL binding to macrophages and therefore enchances cholesterol efflux from cells (Fig. 1).

Significant changes in PON1 can be seen in patients with diabetes mellitus (DM) (type 1 and type 2), where its activity is reduced in contrast to negatively correlated serum SAA levels (Juretic et al. 2006, Kappelle et al. 2011). A PON1 activity depletion was observed in DM type 1 patients with a higher HDL lipid hydroperoxide concentration and was correlated with elevated oxid-LDL levels in DM type 2 subjects (Ferretti et al. 2004, Tsuzura et al. 2004). This data might suggest lower ability of small density $\mathrm{HDL}_{3}$ (fraction with highest PON1 activity) to protect lipoproteins against oxidation in comparison to healthy individuals (Nodecourt et al. 2005).

In diabetes a significant amount of PON1 is dissociated from HDL in serum to the lipoprotein-deficient serum fraction (LPDS). The dissociation of PON1 in diabetic patients could be a result of a partially peroxidized HDL lipoprotein or/and reduced Apo A-I levels. Also PON1 antioxidant activity in the LPDS fraction is reduced when incubated in induced lipid peroxidation conditions. This is in comparison to PON1-HDL bound abilities and leads to a conclusion that only PON1 bound to HDL is able to play a protective role in diabetes against increased oxidative stress (Rosenblat et al. 2005).

\section{PON1 changes in transition period}

Some data has shown changes in PON1 activity around the periparturient period predestined for reactive oxygen species (ROS) formation. Pregnancy and mid lactation period of dairy cows have a great influence on sucrose and lipid metabolic changes. Serum activity of PON1 towards paraoxon was decreased in non - pregnant Holstein-Friesian cows during 8-12 weeks postpartum (Antoncic-Svetina et al. 2011). During this time large adipose mobilization takes place, and concentration of non-esterified fatty acids (NEFAs) and reactive oxygen species in the blood stream is increased (Bionaz et al. 2007). Thus, leading to oxidative stress, enchanced peroxidation and acute phase response (Steinberg 1997, Khovidhunkit et al. 2000), lowering PON1 activity and its' hydrolysis of lipid peroxides. Additionally, around the transition period a negative energy balance could be a factor increasing ROS concentration (Roche et al. 2000, Antoncic-Svetina et al. 2011). PON1, through its activity, protects conversion of free cholesterol to cholesterol esters by lecithin cholesterol acyltransferase (LCAT). This conversion via LCAT leads to HDL core formation (Gan et al. 1991). Serum PON1 activity significantly decreases shortly after parturition in 
comparison to non-pregnant cows (Turk et al. 2004) and its depletion is seen in dairy cow fatty liver syndrome (Farid et al. 2013).

However, animals with an optimal oxidative state, good Edmonson's Body Condition Score (Edmonson et al. 1989) and optimal nutritioning still have decreased serum PON1 activity in postpartum period. The PON1 depletion seems to be a universal pattern seen in different breeds (Kulka et al. 2014, Kulka et al. 2016).

\section{Cooperation with other antioxidant enzymes (markers)}

In DM type 2, a diminished PON1 activity was seen simultaneously to superoxide dismutase (SOD) decrease and catalase (CAT) increase (Sözmen et al. 2001). Moreover, there was a positive correlation between CAT/SOD, CAT/PON1 ratios and glycated hemoglobin concentration. In light of those results PON1 might be used as a marker in control management of diabetes. Moreover, it might possible that paraoxonase plays in concert with other antioxidant systems in vivo, gaining its protection against oxidation thus preserving its antioxidant abilities. Increased PON1 levels, by enchancing LPC production, lead to extracellular expression of SOD in monocyte-macrophages as an antioxidant effect in atherosclerosis, which also might suggest a cooperation of antioxidant systems (Rosenblat et al. 2006).

PON1 plays an important role in protection against oxidative stress present in many diseases. In the acute phase response it acts like negative acute phase protein, with decreased activity. Well studied in human medicine, PON1 assessment gives useful information about many aspects of diseases such as atherosclerosis or DM. PON1 is becoming an important diagnostic tool of redox state disruption in companion and farm animals. However, future studies concerning new implications in veterinary medicine are still to be made.

\section{Acknowledgments}

The study was supported by the NCN grant No. N.N. 308562840 .

\section{References}

Aldrige WN (1953) Serum esterases. I. Two types of esterases (A and B) hydrolysing p-nitrophenyl acetate, propionate and butyrate and a method for their determination. Biochem J 53: 110-117.
Antončić-Svetina M, Turk R, Svetina A, Gereš D, Rekić B, Juretić D (2011) Lipid status, paraoxonase-1 activity and metabolic parameters in serum of heifers and lactating cows related to oxidative stress. Res Vet Sci 90: 298-300.

Aviram M (1999) Does paraoxonase play a role in susceptibility to cardiovascular disease? Mol Med Today 5: 381-386.

Aviram M, Billecke S, Sorenson R, Bisgaier C, Newton R, Rosenblat M, Erogul J, Hsu C, Dunlop C, La Du B (1998A) Paraoxonase active site required for protection against LDL oxidation involves its free sulfhydryl group and is different that required for its arylesterase/paraoxonase activities: selective action of human paraoxonase allozymes Q and R. Arterioscler Thromb Vasc Biol 18: 1617-1624.

Aviram M, Rosenblat M (2004) Paraoxonases 1, 2, and 3, oxidative stress, and macrophage foam cell formation during atherosclerosis development. Free Radic Biol Med 37: 1304-1316.

Aviram M, Rosenblat M, Bisgaier CL, Newton RS, Primo-Parmo SL, La Du BN (1998B) Paraoxonase inhibits high-density lipoprotein oxidation and preserves its functions. A possible peroxidative role for paraoxonase. J Clin Invest 101: 1581-1590.

Azarsiz E, Kayikcioglu M, Payzin S, Yildirim Sözmen E (2003) PON1 activities and oxidative markers of LDL in patients with angiographically proven coronary artery disease. Int J Cardiol 91: 43-51.

Bauchart D (1993) Lipid Absorption and Transport in Ruminants. J Dairy Sci 76: 3864-3881.

Bergmeier C, Siekmeier R, Gross W (2004) Distribution spectrum of paraoxonase activity in HDL fractions. Clin Chem 50: 2309-2315.

Billecke S, Draganov D, Counsell R, Stetson P, Watson C, Hsu C, La Du BN (2000) Human serum paraoxonase (PON1) isozymes Q and R hydrolyze lactones and cyclic carbonate esters. Drug Metab Dispos 28: 1335-1342.

Bionaz M, Trevisi E, Calamari L, Librandi F, Ferrari A, Bertoni G (2007) Plasma paraoxonase, health inflammatory conditions and liver function in trasition dairy cows. J Dairy Sci 90: 1740-1750.

Cao H, Girard-Globa A, Berthezene F, Moulin P (1999) Paraoxonase protection of LDL against peroxidation is independent of its esterase activity towards paraoxon and is unaffected by the Q-->R genetic polymorphism. J Lipid Res 40: 133-139.

Camps J, Garcia-Heredia A, Rull A, Alonso-Villaverde C, Aragonés G, Beltrán-Debón R, Rodrtguez-Gallego E, Joven J (2012) PPARs in regulation of paraoxonases: control of oxidative stress and inflammation pathways. PPAR Res 2012: 616371.

Carr RL, Dail MB, Chambers HW, Chambers JE (2015) Species differences in paraoxonase mediated hydrolysis of several organophosphorus insecticide metabolites. J Toxicol 2015: 470189.

Draganov DI, Teiber JF, Speelman A, Osawa Y, Sunahara $\mathrm{R}$, La Du BN (2005) Human paraoxonases (PON1, PON2, and PON3) are lactonases with overlapping and distinct substrate specificities. J Lipid Res 46: 1239-1247.

Deakin S, Leviev I, Gomaraschi M, Calabresi L, Franceschini G, James RW (2002) Enzymatically active paraoxonase-1 is located at the external membrane of producing cells and released by a high affinity, saturable, desorption mechanism. J Biol Chem 277: 4301-4308. 
Deakin SP, Bioletto S, Bochaton-Piallat ML, James RW (2011) HDL-associated paraoxonase-1 can redistribute to cell membranes and influence sensitivity to oxidative stress. Free Radic Biol Med 50: 102-109.

Eckerson HW, Wyte CM, La Du BN (1983) The human serum paraoxonase/arylesterase polymorphism. Am J Hum Genet 35: 1126-1138.

Edmonson AJ, Lean IJ, Weaver LD, Farver T, Webster G (1989) A Body Condition Scoring chart for Holstein Dairy Cows. J Dairy Sci 72: 69-78.

Erzengin M, Demir D, Arslan M, Sinan S (2014) Purification and characterization of paraoxonase 1 (PON1) from Swiss Black, Holstein, and Montofon bovines. Appl Biochem Biotechnol 173: 1597-1606.

Farid AS, Honkawa K, Fath EM, Nonaka N, Horii Y (2013) Serum paraoxonase-1 as biomarker for improved diagnosis of fatty liver in dairy cows. BMC Vet Res 9: 73.

Feingold KR, Memon RA, Moser AH, Grunfeld C (1998) Paraoxonase activity in the serum and hepatic mRNA levels decrease during the acute phase response. Atherosclerosis 139: 307-315.

Ferretti G, Bacchetti T, Busni D, Rabini RA, Curatola $G$ (2004) Protective effect of paraoxonase activity in high-density lipoproteins against erythrocyte membranes peroxidation: a comparison between healthy subjects and type 1 diabetic patients. J Clin Endocrinol Metab 89: 2957-2962.

Gaidukov L, Viji RI, Yacobson S, Rosenblat M, Aviram M, Tawfik DS (2010) ApoE induces serum paraoxonase PON1 activity and stability similar to ApoA-I. Biochemistry 49: 532-538.

Gan KN, Smolen A, Eckerson HW, La Du BN (1991) Purification of human serum paraoxonase/arylesterase. Evidence for one esterase catalyzing both activities. Drug Metab Dispos 19: 100-106.

Gewurz H, Mold C, Siegel J, Fiedel B (1982) C-reactive protein and the acute phase response. Adv Intern Med 27: 345-372.

Gugliucci A, Caccavello R, Kotani K, Sakane N, Kimura $\mathrm{S}$ (2013) Enzymatic assessment of paraoxonase 1 activity on HDL subclasses: a practical zymogram method to assess HDL function. Clin Chim Acta 415: 162-168.

Jain S, Gautam V, Naseem S (2011) Acute-phase proteins: As diagnostic tool. J Pharm Bioallied Sci 3: 118-127.

Jaouad L, Milochevitch C, Khalil A (2003) PON1 paraoxonase activity is reduced during HDL oxidation and is an indicator of HDL antioxidant capacity. Free Radic Res 37: 77-83.

Juretic D, Motejlkova A, Kunovic B, Rekic B, Flegar-Mestric Z, Vujic L, Mesic R, Lukac-Bajalo J, Simeon-Rudolf $\mathrm{V}$ (2006) Paraoxonase/arylesterase in serum of patients with type II diabetes mellitus. Acta Pharm 56: 59-68.

Karabina SA, Lehner AN, Frank E, Parthasarathy S, Santanam N (2005) Oxidative inactivation of paraoxonase--implications in diabetes mellitus and atherosclerosis. Biochim Biophys Acta 1725: 213-221.

Kappelle PJ, Bijzet J, Hazenberg BP, Dullaart RP (2011) Lower serum paraoxonase-1 activity is related to higher serum amyloid a levels in metabolic syndrome. Arch Med Res 42: 219-225.

Khovidhunkit W, Memon RA, Feingold KR, Grunfeld $C$ (2000) Infection and inflammation-induced proatherogenic changes of lipoproteins. J Infect Dis 181 (Suppl 3): S462-S472.
Kulka M, Bełtowski J, Kluciński W, Ostrowska M, Kołodziejska A, Kleczkowski M (2014) Serum paraoxonase-1 activity of dairy Holstein-Fresian cows in different lactation stages - preliminary study. Pol J Vet Sci 17: 143-147.

Kulka M, Kołodziejska-Lesisz J, Kluciński W (2016) Serum paraoxonase 1 (PON1) activity and lipid metabolism parameters changes in different production cycle periods of Holstein-Friesian, Polish Red and Norwegian breeds. Pol J Vet Sci 19: 165-173.

Li WF, Costa LG, Richter RJ, Hagen T, Shih DM, Tward A, Lusis AJ, Furlong CE (2000) Catalytic efficiency determines the in-vivo efficiency of PON1 for detoxifying organophosphorus compounds. Pharmacogenetics 10: 767-779.

Lusis AJ (2000) Atherosclerosis. Nature 407: 233-241.

Mackness B, Hine D, Liu Y, Mastorikou M, Mackness M (2004) Paraoxonase-1 inhibits oxidised LDL-induced MCP-1 production by endothelial cells. Biochem Biophys Res Commun 318: 680-683.

Mackness MI, Walker CH (1988) Multiple forms of sheep serum A-esterase activity associated with the high-density lipoprotein. Biochem J 250: 539-545.

Méndez JC, Carretón E, Martínez S, Tvarijonaviciute A, Cerón JJ, Montoya-Alonso JA (2014) Acute phase response in dogs with Dirofilaria immitis. Vet Parasitol 204: 420-425.

Miyamoto T, Takahashi Y, Oohashi T, Sato K, Oikawa $\mathrm{S}$ (2005) Bovine paraoxonase 1 activites in serum and distribution in lipoproteins. J Vet Med Sci 67: 243-248.

Navab M, Berliner JA, Subbanagounder G, Hama S, Lusis AJ, Castellani LW, Reddy S, Shih D, Shi W, Watson AD, Van Lenten BJ, Vora D, Fogelman AM (2001) HDL and the Inflammatory Response Induced by LDL-Derived Oxidized Phospholipids. Arterioscler Thromb Vasc Biol 21: 481-488.

Nguyen SD, Sok DE (2003) Oxidative inactivation of paraoxonase-1, an antioxidant protein and its effect on antioxidant action. Free Radic Res 37: 1319-1330.

Nobecourt E, Jacqueminet S, Hansel B, Chantepie S, Grimaldi A, Chapman MJ, Kontush A (2005) Defective antioxidative activity of small dense HDL3 particles in type 2 diabetes: relationship to elevated oxidative stress and hyperglycaemia. Diabetologia 48: 529-538.

Novak F, Vavrova L, Kodydkova J, Novak F Sr, Hynkova M, Zak A, Novakova O (2010) Decreased paraoxonase activity in critically ill patients with sepsis. Clin Exp Med 10: 21-25.

Roche JF, Mackey D, Diskin MD (2000) Reproductive management of postpartum cows. Anim Reprod Sci 60-61: 703-712.

Rosenson RS, Brewer HB Jr, Chapman MJ, Fazio S, Hussain MM, Kontush A, Krauss RM, Otvos JD, Remaley AT, Schaefer EJ (2011) HDL measures, particle heterogeneity, proposed nomenclature, and relation to atherosclerotic cardiovascular events. Clin Chem 57: 392-410.

Rozenberg O, Rosenblat M, Coleman R, Shih DM, Aviram $\mathrm{M}$ (2003) Paraoxonase (PON1) deficiency is associated with increased macrophage oxidative stress: studies in PON1- knockout mice. Free Radic Biol Med 34: 774-784.

Rosenblat M, Vaya J, Shih D, Aviram M (2005) Paraoxonase 1 (PON1) enhances HDL-mediated macrophage cholesterol efflux via the ABCA1 transporter in association with increased HDL binding to the cells: a possible role for lysophosphatidylcholine. Atherosclerosis 179: 69-77. 
Rosenblat M, Oren R, Aviram M (2006) Lysophosphatidylcholine (LPC) attenuates macrophage-mediated oxidation of LDL. Biochem Biophys Res Commun 344: 1271-1277.

Schuller S, Van Israll N, Vanbelle S, Clercx C, McEntee $\mathrm{K}$ (2011) Lack of efficacy of low-dose spironolactone as adjunct treatment to conventional congestive heart failure treatment in dogs. J Vet Pharmacol Ther 34: 322-331.

Shih DM, Xia YR, Wang XP, Miller E, Castellani LW, Subbanagounder G, Cheroutre H, Faull KF, Berliner JA, Witztum JL, Lusis AJ (2000) Combined serum paraoxonase knockout/apolipoprotein E knockout mice exhibit increased lipoprotein oxidation and atherosclerosis. J Biol Chem 275: 17527-17535.

Sorenson RC, Primo-Parmo SL, Camper SA, La Du BN (1995) The genetic mapping and gene structure of mouse paraoxonase/arylesterase. Genomics 30: 431-438.

Sözmen EY, Sözmen B, Delen Y, Onat T (2001) Catalase/superoxide dismutase (SOD) and catalase/paraoxonase (PON) ratios may implicate poor glycemic control. Arch Med Res 32: 283-287.

Steinberg D (1997) Lewis A. Conner Memorial Lecture. Oxidative modification of LDL and atherogenesis. Circulation 95: 1062-1071.
Tsuzura S, Ikeda Y, Suehiro T, Ota K, Osaki F, Arii K, Kumon Y, Hashimoto K (2004) Correlation of plasma oxidized low-density lipoprotein levels to vascular complications and human serum paraoxonase in patients with type 2 diabetes. Metabolism 53: 297-302.

Turk R, Juretic D, Geres D, Turk N, Rekic B, Simeon-Rudolf V, Svetina A (2004) Serum paraoxonase activity and lipid parameters in the early postpartum period of dairy cows. Vet Res Sci 76: 57-61.

Van Lenten BJ, Hama SY, de Beer FC, Stafforini DM, McIntyre TM, Prescott SM, La Du BN, Fogelman AM, Navab M (1995) Anti-inflammatory HDL becomes pro-inflammatory during the acute phase response. Loss of protective effect of HDL against LDL oxidation in aortic wall cell cocultures. J Clin Invest 96: 2758-2767.

Van Lenten BJ, Wagner AC, Nayak DP, Hama S, Navab M, Fogelman AM (2001) High-density lipoprotein loses its anti-inflammatory properties during acute influenza $\mathrm{A}$ infection. Circulation 103: 2283-2288.

Watson CE, Draganov DI, Billecke SS, Bisgaier CL, La Du BN (2001) Rabbits possess a serum paraoxonase polymorphism similar to the human Q192R. Pharmacogenetics 11: 123-134. 